\title{
EFFECTS OF SURFACE PRETREATMENT ON WETTABILITY OF ACACIA MANGIUM WOOD
}

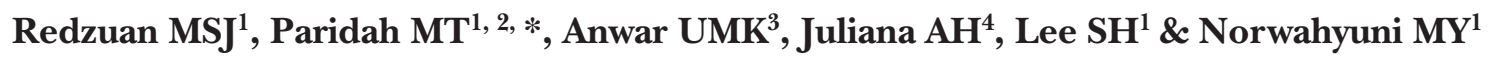 \\ ${ }^{1}$ Institute of Tropical Forestry and Forest Products, Universiti Putra Malaysia, 43400 UPM Serdang, Selangor, Malaysia \\ ${ }^{2}$ Faculty of Forestry, Universiti Putra Malaysia, 43400 UPM Serdang, Selangor, Malaysia \\ ${ }^{3}$ Forest Research Institute Malaysia, 52109 Kepong, Selangor, Malaysia \\ ${ }^{4}$ Faculty of Technology Management and Business, Universiti Tun Hussein Onn Malaysia, 86400 Parit Raja, Batu Pahat, \\ Johore, Malaysia \\ *parida@upm.edu.my
}

Submitted September 2018; accepted January 2019

\begin{abstract}
Furniture manufacturers using Acacia mangium wood often experience difficulties in getting high glossy and attractive finished surface. Such problems may be attributed to poor surface wettability as well as the anatomical structure of the wood itself. This study evaluates the effects of surface treatment on the wettability of $A$. mangium wood. Acacia mangium lumber was segregated into sapwood and heartwood prior to sanding. Two types of solvents, methanol and sodium hydroxide $(\mathrm{NaOH})$ at different concentrations $(2,4,6,8,10$, 12 and 14\%) were used to treat the wood surface. The treated surfaces were evaluated for surface roughness and contact angle according to ISO 4287 and ASTM D7334-08 respectively. The results showed that untreated sapwood of $A$. mangium had significantly rougher surface compared with heartwood after treatment with methanol and $\mathrm{NaOH}$. NaOH-treated surface had relatively lower contact angle than methanol-treated wood and experienced complete wetting within $4.2 \mathrm{~s}$ for sapwood and $6.8 \mathrm{~s}$ for heartwood. The surface was darker and the grain was less visible. Methanol-treated sapwood and heartwood took 6.4 and $12.1 \mathrm{~s}$ respectively to be completely wet but retained its original colour. Their wood grain was clearer and much enhanced. Based on both wettability and appearance, the best results were given by $6 \%$ methanol for sapwood and $4 \%$ methanol for heartwood.
\end{abstract}

Keywords: Methanol, sodium hydroxide, wettability, contact angle, sapwood, heartwood

\section{INTRODUCTION}

Acacia mangium plantation has been established in Peninsular Malaysia, Sabah and Sarawak since 1980's (Muhamad \& Paudyal 1992). Sarawak has the largest $A$. mangium plantation area, with about 289,816 ha in 2012 which makes up $74 \%$ of the planted area in Sarawak. To achieve the targeted planted area of 1 million ha by 2020 , the remaining 710,000 ha is to be planted at a rate of 88,750 ha per year for the next 8 years (Jusoh et al. 2014). The popularity of $A$. mangium wood is due to its excellent strength and machining properties, making it suitable for medium to high end value-added products such as furniture and indoor components (Lim et al. 2003, Paiman et al. 2018). However, A. mangium was reported to be less attractive for wood working due to the presence of knots, cross grain and moderate permeability and wettability (Lim et al. 2011). Such properties are crucial for any wood particularly in finishing process. As a result, the finished surface often sags and paint tailings occurs due to lack of penetration by the lacquers (Omar AS, personal communication). The low wettability of $A$. mangium wood surface was also experienced in bonding. Alamsyah et al. (2008) reported that $A$. mangium laminated board bonded with resorcinol formaldehyde resin has poor shear bond strength. This problem was associated with poor wettability of $A$. mangium that prevented any liquid to sufficiently penetrate the wood surface. Hence a pretreatment is needed to improve the surface wettability of A. mangium.

Surface wettability is an important property for bonding or coating wood. Wettability of A. mangium wood can be improved by pretreating the surface before finishing (Alamsyah et al. 2008). Two types of solvents, namely, methanol and sodium hydroxide $(\mathrm{NaOH})$ improves surface wettability of wood due to their ability to 
remove extractives and contaminants from the wood surface, thereby lowering surface tension and increasing the penetration of liquid (Hse 1972, Alamsyah et al. 2008). In this study, effects of surface pretreatment on the wettability of A. mangium wood were evaluated to determine the treatment that gave the best wettability and appearance.

\section{MATERIALS AND METHODS}

\section{Materials preparation}

Nine-year-old $A$. mangium wood of size $1000 \mathrm{~mm}$ $\times 60 \mathrm{~mm} \times 20 \mathrm{~mm}$ with density of $634 \mathrm{~kg} \mathrm{~m}^{-3}$ and moisture content of $12 \pm 3 \%$ were provided by Nusantara Kraft Company, Sarawak. The lumbers were cut into $60 \mathrm{~mm}$ long $\times 20 \mathrm{~mm}$ wide $\times 20 \mathrm{~mm}$ thick sapwood and heartwood samples prior to surface treatment (Figure 1). Several light strokes were applied sequentially to the surface of each sample using sandpaper of 100, 180 and 360 grits before being dried in an oven at $103 \pm 2{ }^{\circ} \mathrm{C}$. The moisture content was determined after 3 hours and the subsequent hours, until it reached 8 $\pm 2 \%$, a level that is suitable for finishing work (Sonmez et al. 2009). Samples were cooled in a desiccator for $20 \mathrm{~min}$ prior to determining their moisture contents.

\section{Pretreatment method}

Two bleaching reagents were used, namely, methanol and $\mathrm{NaOH}$. These chemicals were analytical grade and were commercially

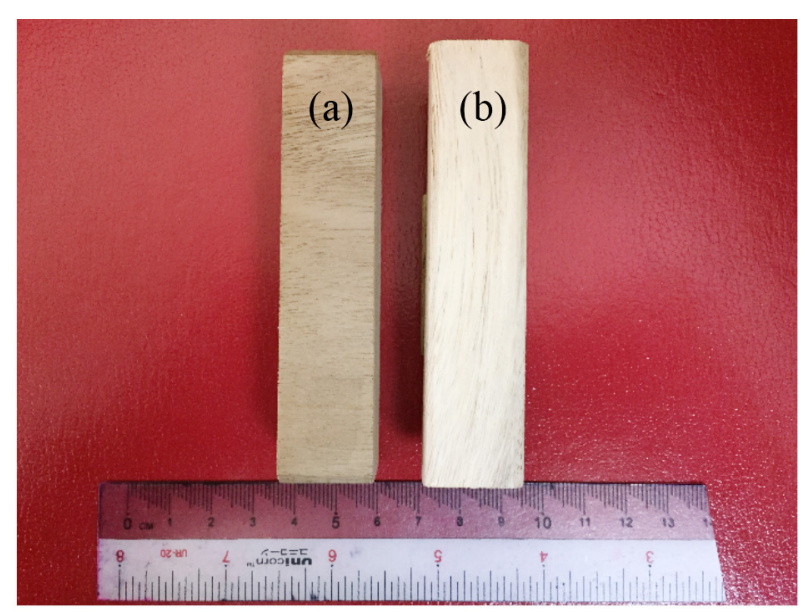

Figure 1 Acacia mangium wood sample; (a) heartwood with dark brown colour and (b) sapwood with yellow pale colour available. Distilled water was used to dilute the solvents to different concentrations, i.e. $2,4,6,8,10,12$ and $14 \%$. The surfaces of wood samples were wiped with a cloth that was wetted with different concentrations of $\mathrm{NaOH}$ or methanol while ensuring sufficient wetting and consistent coverage of the surfaces were attained. The samples were then air dried at ambient temperature for 24 hours prior to testing.

\section{pH and buffering capacity}

The buffering capacity was determined following the method described by Paridah et al. (2009) and He and Yan (2005). Untreated A. mangium wood sample was ground and dried and $15 \mathrm{~g}$ of the dry A. mangium particles was boiled in $200 \mathrm{~mL}$ flask for $30 \mathrm{~min}$. The mixture was then filtered using glass crucibles with filter porosity 2 (40$100 \mu \mathrm{m})$ equipped with an aspirator vacuum. The filtrates were diluted with distilled water to final volume of $200 \mathrm{~mL}$ each and cooled at $20{ }^{\circ} \mathrm{C}$ for 24 hours. $\mathrm{pH}$ values of the diluted solvents were determined before aqueous extraction. Aqueous extract was manually titrated using $0.1 \mathrm{~N} \mathrm{NaOH}$ and $0.1 \mathrm{~N}$ hydrochloride $(\mathrm{HCl})$ solution until $\mathrm{pH} 10.0$ and $\mathrm{pH} 3.0$ respectively. The $\mathrm{pH}$ value was recorded after the addition of every $0.2 \mathrm{~mL}$ of titrant.

\section{Surface roughness}

Surface roughness of sapwood and heartwood samples was determined before and after being wiped with methanol and $\mathrm{NaOH}$. Although there are various roughness measurement techniques including pneumatic, laser and light scattering methods, stylus type of profilometer is the most commonly used technique due to its practicality and accurate numerical results. This test was performed by profile method using stylus device based on standard ISO 4287 (ISO 1998). The measuring speed, pin diameter, and pin top angle of the tool were $5 \mathrm{~mm} \mathrm{~min}^{-1}, 5 \mu \mathrm{m}$, and $90^{\circ}$ respectively. Average surface roughness $(\mathrm{Ra})$ and mean peak-to-valley height $(\mathrm{Rz})$ were two parameters measured. Readings were taken perpendicular to the grain direction using $15-\mathrm{mm}$ tracing length. Five random measurements were collected for each specimen. 


\section{Evaluation of contact angle}

The wettability measurement was performed according to ASTM D7334-08 (ASTM 2008). Contact angle measurement was taken for different parts of treated and untreated sapwood and heartwood using droplets of $3.0 \mu \mathrm{L}$ distilled water at $20{ }^{\circ} \mathrm{C}$. Relative humidity in the testing room was $65 \pm 5 \%$. Readings were taken until no water droplet was left on the wood surface and five measurements were collected for each specimen.

\section{Statistical analysis}

Statistical analysis software was used to analyse the data obtained in the study. An analysis of variance (ANOVA) and mean separation using least significant difference (LSD) were conducted to evaluate the effect of different concentrations of methanol and $\mathrm{NaOH}$ on the surface roughness and wettability of $A$. mangium wood.

\section{RESULTS AND DISCUSSION}

\section{Buffering capacity of $A$. mangium}

Resistance of wood material to the change in its $\mathrm{pH}$ level is called buffer capacity. The $\mathrm{pH}$ value and buffering capacity information are fundamental to understanding the curing behaviour of resin (He \& Yan 2005, Paridah et al. 2009). Both $\mathrm{pH}$ and buffering capacity influence the effectiveness of surface treatment. Acacia mangium appeared to be more stable in acidic than in alkaline condition since it required higher amount of $\mathrm{HCl}(8.8 \mathrm{~mL})$ to reach $\mathrm{pH}$ 3 while it takes only $2.0 \mathrm{~mL} \mathrm{NaOH}$ for the A. mangium to reach $\mathrm{pH} 10$ from the initial $\mathrm{pH}$ of 5.08 (Figure 2). In a similar study, Nurhazwani et al. (2015) found that bamboo (Dendrocalamus asper) required $5.5 \mathrm{~mL}$ of $\mathrm{HCl}$ to change its $\mathrm{pH}$ from 4.3 to 3.0 , while rubberwood needed only $4.5 \mathrm{~mL}$ to change its $\mathrm{pH}$ from 4 to $\mathrm{pH} 3$. On the other hand, the amount of $\mathrm{NaOH}$ required to change the initial $\mathrm{pH}$ to 10 for both bamboo and rubberwood were approximately the same, i.e. between 74.5 and $77 \mathrm{~mL}$, which was much higher than the amount needed for A. mangium. Wood that requires a large amount of acid to decrease its $\mathrm{pH}$ is considered as having high buffering capacity (Maloney 1977). Hence A. mangium had low buffering capacity in alkali as shown by the sudden increase in $\mathrm{pH}$ after a small addition of $\mathrm{NaOH}(2.0 \mathrm{~mL})$.

This study suggested that there will be difficulties with $A$. mangium wood when using basic coating system as $\mathrm{pH}$ of the wood surface will change once it is associated with any alkalibased system. Such behaviour will change the curing rate of the coating material itself or of the coating material on the wood surface as well as in the cells. As a result, the rate of curing can be altered to be slower to faster. However, such changes are troublesome particularly in achieving good adhesion between the finishing and wood (Johns \& Niazi 2007). High buffering capacity in bamboo had slowed down the curing time of melamine formaldehyde, melamine urea phenol formaldehyde and phenol formaldehyde

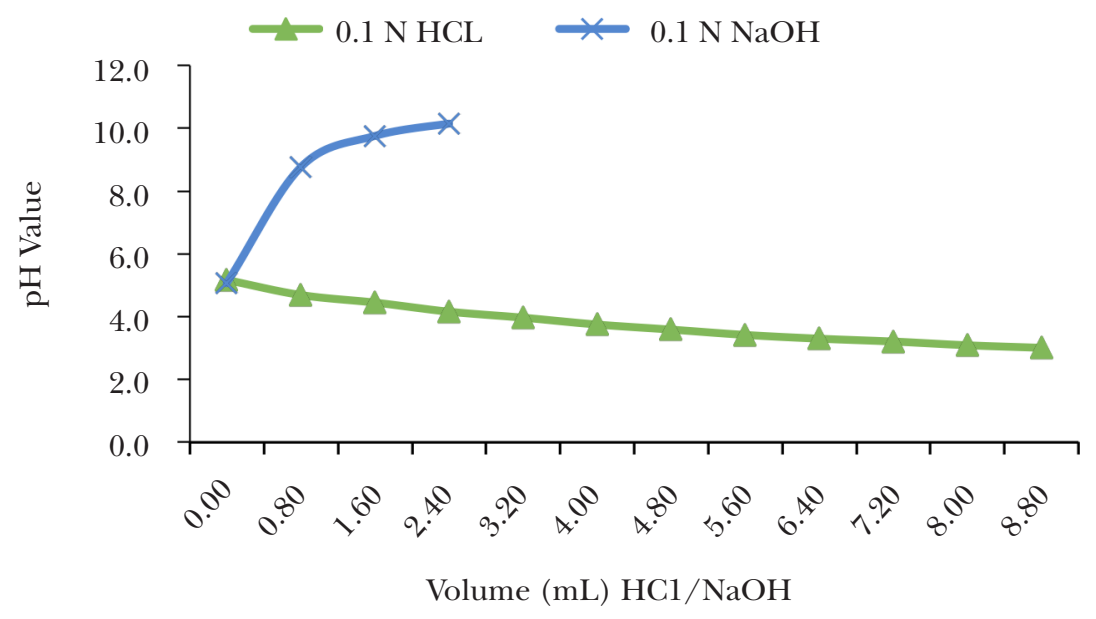

Figure 2 Stability of Acacia mangium in acidic and alkaline condition 
resin adhesives resulting in lower bond strength of the bamboo composites (Malanit et al. 2009). Meanwhile, as A. mangium had high acid buffering capacity, it is recommended that some amount of acid catalyst should be added when applying acid-based coatings such as nitrocellulose, acid catalyst or polyurethane lacquers $(\mathrm{pH}$ ranges from 4-6).

\section{Appearance of A. mangium}

According to Tenorio et al. (2012), A. mangium has distinct coloration between sapwood and heartwood. Sapwood is often white or yellowishwhite and the heartwood is yellowish brown to golden brown when fresh, and change to dull brown upon long exposure to light and air as shown in Figure 3a. Natural wood pattern provides artistic enjoyment and colours and patterns significantly differ from one wood species to another. The colour of furniture is so important for its appearance and must remain as uniform as possible to ensure aesthetic effect (Keey 2005). NaOH-treated A. mangium wood has darker colour compared with methanol-treated sample. However, $\mathrm{NaOH}$-treated wood also has poor wood appearance (water mark) as shown in Figure 3. Surface treatment with high $\mathrm{pH}$ occasionally darkens wood as tannin in the wood is brought to the wood surface by solvents. Dark iron tannate discoloration occurs once the tannin reacts with microscopic metals particles, resulting in darkened wood surface. On the other hand, methanol-treated samples retained its original light colour and therefore was more favourable for finishing application compared with $\mathrm{NaOH}-$ treated samples.

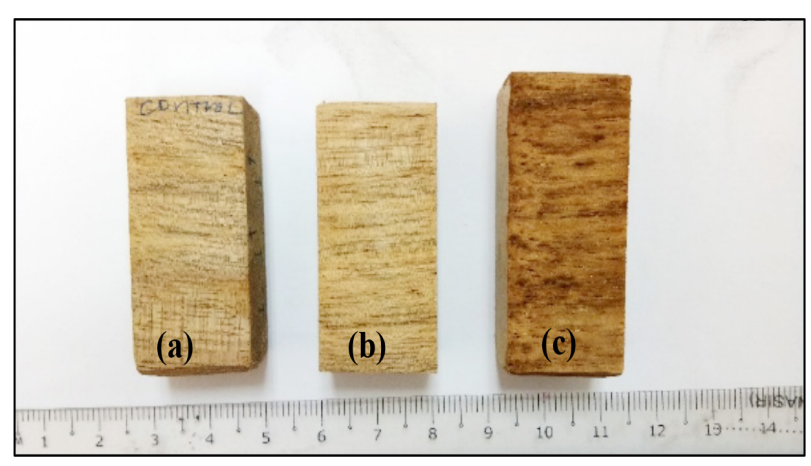

Figure 3 Appearance of Acacia mangium wood; (a) control, (b) methanol-treated and (c) $\mathrm{NaOH}$-treated samples

\section{Surface roughness}

Surface roughness is influenced by cross grain, annual growth ring width, rays, knots, reaction wood, and ratio of earlywood and latewood (Sulaiman et al. 2009). Surface roughness of A. mangium prior to finishing is very crucial in determining the quality of the finished product. Ra and mean $\mathrm{Rz}$ were considered for evaluation of different per cent of concentration of methanol and $\mathrm{NaOH}$ samples. $\mathrm{Ra}$ is the average distance from profile to the mean line, which is the least square average of the profile, whereas $\mathrm{Rz}$ can be defined as an average of five consecutive mean peak-to-valley height within the profile (Hiziroglu \& Graham 1998). Lower rates of $\mathrm{Ra}$ and $\mathrm{Rz}$ are favourable because a smooth surface needs relatively little paint for coverage, and paint performance is improved (Jakub \& Martino 2005).

Table 1 tabulates the ANOVA and mean separation using LSD method of the effect of different concentrations of methanol and $\mathrm{NaOH}$ towards two parts of wood, sapwood and heartwood. The results showed that there were significant differences for $\mathrm{Ra}$ and $\mathrm{Rz}$ in terms of parts of wood (sapwood and heartwood), types of treatment (methanol and $\mathrm{NaOH}$ ) and percentages of concentrations, but there was no difference between the interaction of part of wood and type of treatment, part of wood and concentration, type of treatment and concentration, and part of wood and type of treatment and concentration.

Different parts of wood gave different outcomes to the surface roughness ( $\mathrm{Ra}$ and $\mathrm{Rz}$ ) values. Sapwood had higher $\mathrm{Ra}$ and $\mathrm{Rz}$ than heartwood. The surface profile of sapwood is easily affected by sanding due to the capillaryporous nature of wood itself. Therefore, during surface treatment process, the surface of the sapwood and a thin layer below it are in movement, causing surface distortion (raised grain) and changes in surface roughness (Csanády et al. 2015). With increasing surface roughness, the spreading and penetration of liquids/water on the surface of wood increase (Sulaiman et al. 2009). Rough surface can promote over penetration by increasing true surface area and increase the tendency in capturing higher amount of water (Neese et al. 2004, Ratnasingam \& Scholz 2006). Sapwood may have greater ability to absorb liquid/water 
Table 1 Analysis of variance for the effects of different variables on surface roughness of Acacia mangium

\begin{tabular}{|c|c|c|c|c|c|}
\hline \multirow[t]{2}{*}{ Source } & \multirow[t]{2}{*}{$\mathrm{df}$} & \multicolumn{2}{|c|}{$\mathrm{Ra}$} & \multicolumn{2}{|c|}{$\mathrm{Rz}$} \\
\hline & & $\mathrm{p}$-value & & p-value & \\
\hline Part of wood $(\mathrm{P})$ & 1 & $<0.0001$ & $* * *$ & $<0.0001$ & $* * *$ \\
\hline Treatments $(\mathrm{T})$ & 1 & 0.0037 & $* * *$ & 0.0140 & $* *$ \\
\hline Concentration (C) & 6 & 0.0011 & $* * *$ & 0.0003 & $* * *$ \\
\hline $\mathrm{P} * \mathrm{~T}$ & 1 & 0.0910 & ns & 0.0926 & ns \\
\hline $\mathrm{P} * \mathrm{C}$ & 6 & 0.9500 & ns & 0.9065 & ns \\
\hline $\mathrm{T} * \mathrm{C}$ & 6 & 0.9988 & ns & 0.9946 & ns \\
\hline $\mathrm{P} * \mathrm{~T} * \mathrm{C}$ & 6 & 0.9987 & ns & 0.9914 & ns \\
\hline
\end{tabular}

$* * *=$ significant difference at $\mathrm{p}<0.01, * *=$ significant difference at $\mathrm{p}<0.05 ; \mathrm{ns}=$ no significant difference

compared with heartwood. The highest Ra for part of wood was recorded in sapwood at $5.11 \mu \mathrm{m}$ followed by heartwood at $3.31 \mu \mathrm{m}$, while the highest $\mathrm{Rz}$ for part of wood was recorded at $31.84 \mu \mathrm{m}$ for sapwood followed by $22.77 \mu \mathrm{m}$ for heartwood (Figure $4 \mathrm{a}$ ). $\mathrm{NaOH}$ produced rougher surface (higher $\mathrm{Ra}$ and $\mathrm{Rz}$ values) than methanol (Figure 4b). The highest Ra was recorded by $\mathrm{NaOH}$ at $4.75 \mu \mathrm{m}$ followed by methanol at $3.66 \mu \mathrm{m}$. The highest $\mathrm{Rz}$ values was recorded by $\mathrm{NaOH}$ at $29.89 \mu \mathrm{m}$ and followed by methanol at $24.72 \mu \mathrm{m}$ respectively.

Table 2 shows the surface roughness values of A. mangium treated with different concentrations of methanol and $\mathrm{NaOH}$. Untreated A. mangium had smoother surface compared with treated samples for both sapwood and heartwood. Treatment using $\mathrm{NaOH}$ and methanol increased the roughness of wood surface but was pronounced in the sapwood. Surface roughness of the sapwood changed significantly when $\geq 6 \% \mathrm{NaOH}$ was used while the significant change in surface roughness for heartwood was already observed when only $2 \% \mathrm{NaOH}$ were applied (Table 2). Nevertheless, methanoltreated sapwood and heartwood surface behaved differently. For sapwood, changes in roughness were quite similar to those of $\mathrm{NaOH}$-treated samples. For heartwood, changes in surface roughness were opposite to that of $\mathrm{NaOH}$ treated samples. The surface roughness changed significantly after treatment with $12 \%$ methanol. Heartwood contains substantial amount of extractives that accumulate in the lumen. Unlike methanol, $\mathrm{NaOH}$ can easily dissolve some of these extractive components, making $\mathrm{NaOH}$ easier to penetrate into several cell layers. Sample surface were rougher when using methanol and more amount of solvent was needed to dissolve the extractives. 'Roughing' wood surface is common during wood finishing as it helps to increase surface area for the bonding of coating material. However, rougher surface will contribute to excessive volume of liquid/water penetration, thus increasing the finishing cost. Surface topography is an important criterion that affects good penetration and aesthetic value of wood in terms of touch and appearance (Jakub \& Martino 2005).

\section{Evaluation of surface wettability}

In the wettability study, contact angle formed between the surface and liquid provides useful information on how well the adhesives wet, spread and penetrate the wood (Paridah et al. 2009). Table 3 summaries the ANOVA results of the effects of different parts of wood (sapwood and heartwood), solvents (methanol and $\mathrm{NaOH}$ ) and their concentrations on the contact angles of $A$. mangium. The results showed that all the parameters studied had significant influence on the contact angle and wettability of $A$. mangium. Surface treatment minimised surface area so that the number of intermolecular bonds in the surface might be reduced and penetration could occur. The continuous contact between the adhesive and adherend is called wetting. Adhesion occurs by the penetration of adhesives into pores of the substrate and the coating with better penetration and substrate wetting show superior adhesion (Lu 2006). 
(a)

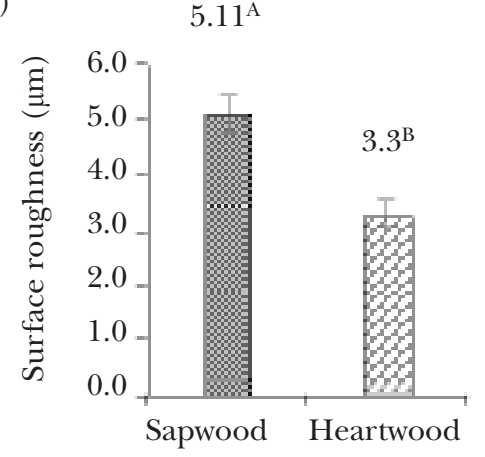

(b)

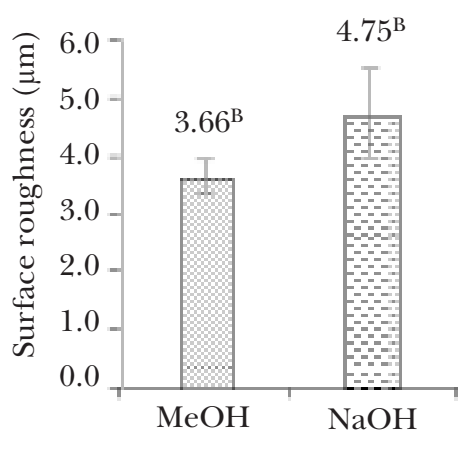

Type of treatment

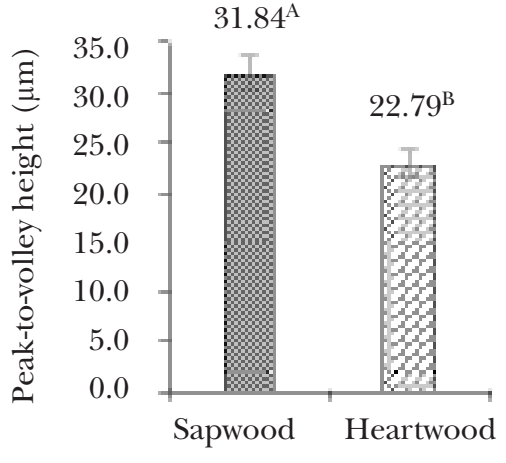

Part of wood

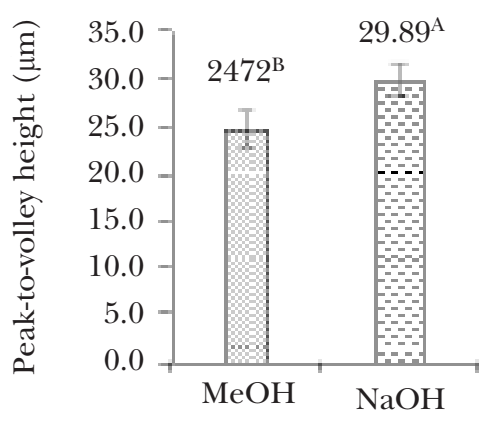

Type of treatment

Figure 4 Comparison of average surface roughness and mean peak-to-valley height between (a) sapwood and heartwood and (b) methanol and $\mathrm{NaOH}$; bars having the same letters are not significantly different at $\mathrm{p} \leq 0.05$

Table 2 Average surface roughness $(\mathrm{Ra}, \mu \mathrm{m})$ and mean peak-to-valley height $(\mathrm{Rz}, \mu \mathrm{m})$ of Acacia mangium wood treated with methanol and $\mathrm{NaOH}$

\begin{tabular}{|c|c|c|c|c|}
\hline \multirow[t]{3}{*}{ Concentration (\%) } & \multicolumn{2}{|c|}{ Methanol } & \multicolumn{2}{|c|}{$\mathrm{NaOH}$} \\
\hline & \multicolumn{4}{|c|}{ Sapwood } \\
\hline & $\mathrm{Ra}$ & $\mathrm{Rz}$ & $\mathrm{Ra}$ & $\mathrm{Rz}$ \\
\hline Control & $2.41^{\mathrm{b}}(0.24)$ & $17.65^{\mathrm{b}}(1.68)$ & $2.41^{\mathrm{b}}(0.24)$ & $17.65^{\mathrm{b}}(1.68)$ \\
\hline 2 & $3.26^{\mathrm{b}}(1.11)$ & $20.97^{\mathrm{b}}(5.96)$ & $3.60^{\mathrm{b}}(1.50)$ & $25.57^{\mathrm{b}}(10.49)$ \\
\hline 4 & $3.97^{\mathrm{b}}(1.37)$ & $24.75^{\mathrm{b}}(7.81)$ & $3.89^{\mathrm{b}}(0.28)$ & $25.08^{\mathrm{b}}(2.36)$ \\
\hline 6 & $4.69^{\mathrm{a}}(1.19)$ & $33.38^{\mathrm{a}}(9.50)$ & $5.02^{\mathrm{a}}(3.35)$ & $31.27^{\mathrm{a}}(12.05)$ \\
\hline 8 & $4.75^{\mathrm{a}}(2.17)$ & $28.82^{\mathrm{b}}(13.40)$ & $5.99^{\mathrm{a}}(2.62)$ & $33.39^{\mathrm{a}}(12.85)$ \\
\hline 10 & $4.80^{\mathrm{a}}(1.34)$ & $30.95^{\mathrm{a}}(7.63)$ & $5.60^{\mathrm{a}}(1.49)$ & $33.82^{\mathrm{a}}(4.70)$ \\
\hline 12 & $5.99^{\mathrm{a}}(2.62)$ & $33.39^{\mathrm{a}}(12.85)$ & $6.27^{\mathrm{a}}(3.75)$ & $37.72^{\mathrm{a}}(21.23)$ \\
\hline 14 & $6.63^{\mathrm{a}}(1.95)$ & $44.72^{\mathrm{a}}(12.33)$ & $7.04^{\mathrm{a}}(0.68)$ & $41.88^{\mathrm{a}}(3.78)$ \\
\hline \multicolumn{5}{|c|}{ Heartwood } \\
\hline & $\mathrm{Ra}$ & $\mathrm{Rz}$ & $\mathrm{Ra}$ & $\mathrm{Rz}$ \\
\hline Control & $1.32^{\mathrm{b}}(0.30)$ & $9.06^{\mathrm{b}}(1.08)$ & $1.32^{\mathrm{b}}(0.30)$ & $9.06^{\mathrm{b}}(1.08)$ \\
\hline 2 & $1.41^{\mathrm{b}}(0.41)$ & $10.25^{\mathrm{b}}(4.99)$ & $3.35^{\mathrm{a}}(0.84)$ & $21.12^{\mathrm{a}}(9.67)$ \\
\hline 4 & $1.81^{\mathrm{b}}(0.81)$ & $13.85^{\mathrm{b}}(7.55)$ & $3.44^{\mathrm{a}}(1.41)$ & $21.38^{\mathrm{a}}(10.71)$ \\
\hline 6 & $2.07^{\mathrm{b}}(0.63)$ & $15.06^{\mathrm{b}}(6.99)$ & $3.47^{\mathrm{a}}(1.37)$ & $25.20^{\mathrm{a}}(6.47)$ \\
\hline 8 & $2.19^{\mathrm{b}}(0.90)$ & $20.02^{\mathrm{b}}(8.13)$ & $3.77^{\mathrm{a}}(1.53)$ & $24.94^{\mathrm{a}}(10.45)$ \\
\hline 10 & $2.58^{\mathrm{b}}(0.65)$ & $17.63^{\mathrm{b}}(5.28)$ & $4.38^{\mathrm{a}}(1.50)$ & $27.10^{\mathrm{a}}(8.79)$ \\
\hline 12 & $3.57^{\mathrm{a}}(0.52)$ & $26.74^{\mathrm{a}}(7.17)$ & $5.14^{\mathrm{a}}(1.89)$ & $36.11^{\mathrm{a}}(5.58)$ \\
\hline 14 & $3.49^{\mathrm{a}}(0.75)$ & $25.59^{\mathrm{a}}(4.15)$ & $5.60^{\mathrm{a}}(1.49)$ & $33.82^{\mathrm{a}}(4.70)$ \\
\hline
\end{tabular}

Means followed with the same letter in the same column are not significantly different at $\mathrm{p} \leq 0.05$ 
Table 3 Analysis of variance of the effects of part of wood, treatment and concentrations on the contact angle of Acacia mangium

\begin{tabular}{lccc}
\hline Source & $\mathrm{df}$ & $\mathrm{p}$-value & \\
\hline Part of wood $(\mathrm{P})$ & 1 & $<0.0001$ & $* * *$ \\
Treatment $(\mathrm{T})$ & 1 & $<0.0001$ & $* * *$ \\
Concentration $(\mathrm{C})$ & 6 & $<0.0001$ & $* * *$ \\
$\mathrm{P} * \mathrm{~T}$ & 1 & 0.0034 & $* * *$ \\
$\mathrm{P} * \mathrm{C}$ & 6 & $<0.0001$ & $* * *$ \\
$\mathrm{~T} * \mathrm{C}$ & 6 & $<0.0001$ & $* * *$ \\
$\mathrm{P} * \mathrm{~T} * \mathrm{C}$ & 6 & $<0.0001$ & $* * *$ \\
\hline
\end{tabular}

***highly significant differentce at $\mathrm{p}<0.01$

Methanol and $\mathrm{NaOH}$-treated samples experienced some enhancement in wetting compared with untreated samples (control) irrespective of the concentration used. Acacia mangium wood had high resistance towards acid but less resistance towards alkaline. Surface wettability values of $A$. mangium sapwood and heartwood treated with different concentrations of $\mathrm{NaOH}$ and methanol as indicated by the time needed for the contact angle of the water droplet to reach $0^{\circ}$ are shown in Figures 5-8. The largest contact angle recorded by untreated sapwood (Figures 5 and 6) and heartwood (Figures 7 and 8 ) was $83.0^{\circ}$ and $80.8^{\circ}$ respectively which took 92.2 and $130.3 \mathrm{~s}$ to reach $0^{\circ}$ (not shown in the figure). Sapwood and heartwood samples treated with $2 \% \mathrm{NaOH}$ only needed 4.22 and $6.81 \mathrm{~s}$ to reach $0^{\circ}$ as shown in Figure 5 and Figure 7 respectively. Meanwhile, 6 (Figure 6 ) and $4 \%$ (Figure 8) methanol were the most effective in increasing the wettability of $A$. mangium sapwood and heartwood respectively. To reach $0^{\circ}$, the fastest times for both types of wood were $6.41 \mathrm{~s}$ shown by sapwood treated with $6 \%$ methanol (Figure 6) and 12.11 s (Figure 8) by heartwood treated with $4 \%$ methanol.

The surface wettability did not show significant improvement when higher concentration of $\mathrm{NaOH}(\geq 10 \%)$ was used as the times needed for the contact angles to reach $0^{\circ}$ were longer as shown in Figures 5 and 7. However, when the concentration of $\mathrm{NaOH}$ was $<10 \%$, the improvement was obvious. Concentration had much larger influence on contact angle as higher concentration of solvents only gave slight increment in wettability while at lower concentration, the time needed to reach $0^{\circ}$ was shortened especially for $\mathrm{NaOH} \leq 6 \%$. On the other hand, for methanol-treated samples, solvent concentrations ranged from 4-12\% gave good results in improving the surface wettability, where the best concentration was $6 \%$ for sapwood and $4 \%$ for heartwood as mentioned before. Too low $(2 \%)$ or too high $(14 \%)$ of the methanol concentration did not bring significant improvement in surface wettability of A. mangium. Wettability of sapwood was relatively higher because it had higher surface roughness compared with heartwood. Sapwood contains living cells hence usually have thinner cell wall and larger lumen diameter that is filled with water while heartwood contains mainly dead cells with high amount of extractives in the lumen (Hoadley 2000, Taylor et al. 2007). Upon drying, the cell wall and lumen of sapwood will form greater number of voids compared with heartwood. During machining, these voids will be cut through, exposing the empty lumen and creating open grains which are responsible for the rough surfaces which significantly affect the wettability (Busscher et al. 1984, Petrič 2013). Wettability is also determined by type of liquid, extractives, time and wood species (Wålinder \& Johansson 2001).

\section{CONCLUSIONS}

This study investigated the influence of surface treatment using methanol and $\mathrm{NaOH}$ at different percentages as a way to enhance the surface wettability of $A$. mangium towards its use as a high-end product. Acacia mangium appeared to be more stable in acidic than in alkaline condition. It has low buffering capacity in alkali as shown by a sudden increase in $\mathrm{pH}$ after a small addition of $\mathrm{NaOH}$. Overall, the type of solvent 


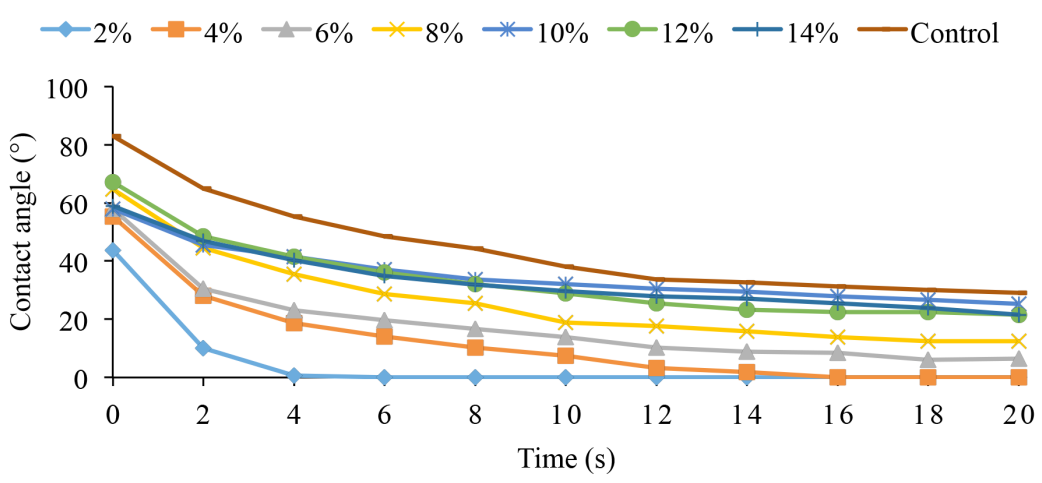

Figure 5 Surface wettability (time needed in s for the water droplet to reach $0^{\circ}$ ) of Acacia mangium sapwood treated with different concentrations of $\mathrm{NaOH}$

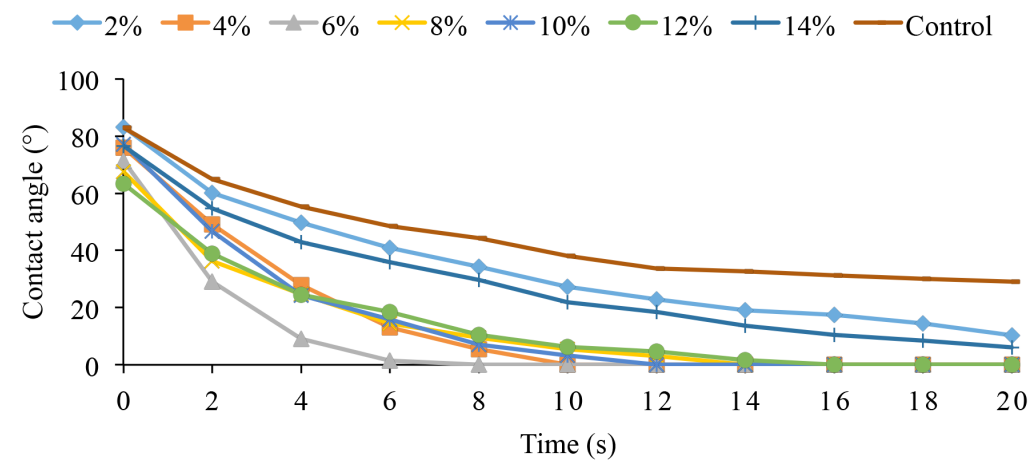

Figure 6 Surface wettability of Acacia mangium sapwood treated with different concentrations of methanol

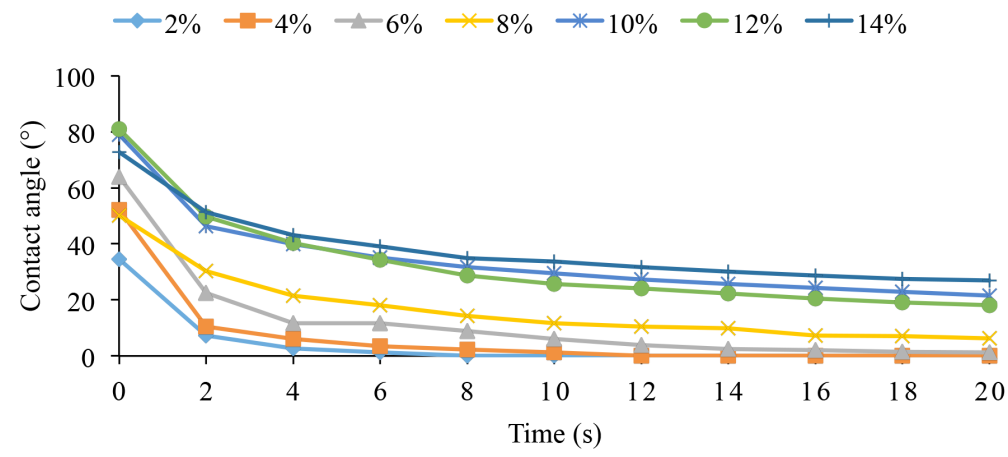

Figure 7 Surface wettability of Acacia mangium heartwood treated with different concentration of $\mathrm{NaOH}$

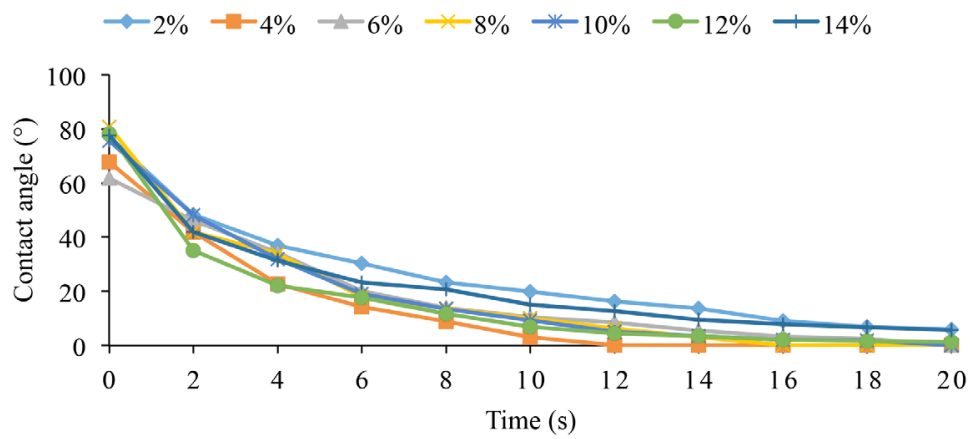

Figure 8 Surface wettability Acacia mangium heartwood treated with different concentration of methanol 
and its concentrations had significant effect on the surface roughness and wettability of $A$. mangium wood. Methanol and $\mathrm{NaOH}$ were able to increase the wettability of $A$. mangium wood surface, irrespective of sapwood or heartwood. Heartwood responded better to surface treatment compared with sapwood. Between $\mathrm{NaOH}$ and methanol, the former was more effective in improving the surface wettability of wood but it caused unfavourable change in colour of the wood. Treatment with $6 \%$ methanol for sapwood and $4 \%$ methanol for heartwood significantly improved the wettability of A. mangium wood. Surface treatment with alkali $(\mathrm{NaOH})$ darkened the wood as the tannin in the wood was brought to the wood surface by the solvent. Meanwhile, methanol-treated samples retained its original light colour and therefore was more favourable for finishing application.

\section{ACKNOWLEDGEMENTS}

The authors wish to thank the Higher Institutions Centres of Excellence, Ministry of Higher Education for the financial support (project no. 6369109) and Wood Finishing Laboratory, Forest Research Institute Malaysia for the facilities used during the study.

\section{REFERENCES}

Alamsyah EM, Yamada M \& Taki K. 2008. Bondability of tropical fast-growing tree species. III: Curing behavior of resorcinol formaldehyde resin adhesive at room temperature and effects of extractives of Acacia mangium wood on bonding. Journal of Wood Science 54: 208-213.

ASTM (American Society for Testing and Materials). 2008. ASTM D7334-08 Standard Practice for Surface Wettability of Coatings, Substrates and Pigments by Advancing Contact Angle Measurement. ASTM International, West Conshohocken.

Busscher H, Van Pelt A, De Boer P, De Jong H \& Arends J. 1984. The effect of surface roughening of polymers on measured contact angles of liquids. Colloids and Surfaces 9: 319-331.

Csanády E, Magoss E \& Tolvaj L. 2015. Surface roughness of wood. Pp 183-236 in Csanady et al. (eds) Quality of Machined Wood Surfaces. Springer International Publishing, Switzerland.

HE G \& YAN N. 2005. Effect of wood on the curing behavior of commercial phenolic resin systems. Journal of Applied Polymer Science 95: 185-192.

Hiziroglu S \& Graham M. 1998. Effect of press closing time and target thickness on surface roughness of particleboard. Forest Products Journal 48: 50-54.

Hoadley RB. 2000. Understanding Wood: A Craftsman's Guide to Wood Technology. Taunton Press, Newtown.
Hse CY. 1972. Wettability of southern pine veneer by phenol formaldehyde wood adhesives. Forest Products Journal 22: 51-56.

ISO (INTERNATIONAL ORGANIZATION FOR STANDARDIZATION). 1998. ISO 4287: 1997: Geometrical Product Specifications (GPS)— Surface Texture: Profile Method-Terms, Definitions and Surface Texture Parameters. International Organization for Standardization, Geneva.

Jakub S \& Martino N. 2005. Wood Surface Roughness-What is It? Trees and Timber Research Institute, IVALSA/ CNR, Via Biasi.

JoHns WE \& NiAzI KA. 2007. Effect of pH and buffering capacity of wood on the gelation time of ureaformaldehyde resin. Wood and Fiber Science 12: 255-263.

Jusoh I, Abu Zaharin F, AdAm NS. 2014. Wood quality of Acacia hybrid and second-generation Acacia mangium. BioResources 9: 150-160.

KeEY RB. 2005. Colour development on drying. MaderasCiencia y tecnología 7: 3-16.

Lim SC, Gan KS \& Choo KT. 2003. The Characteristics, Properties and Uses of Plantation Timbers-Rubberwood and Acacia mangium. Timber Technology Bulletin No. 26, Forest Research Institute Malaysia, Kepong.

Lim SC, GAN KS \& TAN YE. 2011. Properties of Acacia mangium Planted in Peninsular Malaysia: ITTO Project on Improving Utilisation and Value Adding of Plantation Timbers From Sustainable Sources in Malaysia. Project No. PD 306/04 (1). Forest Research Institute Malaysia, Kepong.

LU KT. 2006. Effects of hydrogen peroxide treatment on the surface properties and adhesion of ma bamboo (Dendrocalamus latiflorus). Journal of Wood Science 52: 173-178.

Malanit P, Barbu M \& Frühwald A. 2009. The gluability and bonding quality of an Asian bamboo (Dendrocalamus asper) for the production of composite lumber. Journal of Tropical Forest Science 21: 361-368.

Maloney TM. 1977. Modern Particleboard and Dry-Process Fiberboard Manufacturing. Miller Freeman Publications Inc., San Francisco.

Muhamad MN \& Paudyal BK. 1992. Pruning trial for Acacia mangium Willd. plantation in Peninsular Malaysia. Forest Ecology and Management 47: 285-293.

Neese J, Reeb J \& Funck J. 2004. Relating traditional surface roughness measures to gluebond quality in plywood. Forest Products Journal 54: 67-73.

Nurhazwani O, Jawaid M, Tahir PM, Abdul JH \& Hamid SA. 2015. Hybrid particleboard made from bamboo (Dendrocalamus asper) veneer waste and rubberwood (Hevea brasilienses). BioResources 11: 306-323.

Paiman B, Lee SH, Zaidon A. 2018. Machining properties of natural regeneration and planted Acacia mangium $\times$ A. auriculiformis hybrid. Journal of Tropical Forest Science 30: 135-142.

Paridah M, Hafizah AN, Zaidon A, Azmi I, Nor MM \& Yuziah MN. 2009. Bonding properties and performance of multi-layered kenaf board. Journal of Tropical Forest Science 21: 113-122.

Petrič M. 2013. Surface modification of wood. Reviews of Adhesion and Adhesives 1: 216-247.

RATNASINGAM J \& SchOlz F. 2006. Optimal surface roughness for high-quality finish on rubberwood (Hevea brasiliensis). Holz als Roh- und Werkstoff 64: 343-345. 
Sonmez A, Budakci M \& Bayram M. 2009. Effect of wood moisture content on adhesion of varnish coatings. Scientific Research and Essays 4: 1432-1437.

Sulaiman O, Hashim R, Subari K \& Liang C. 2009. Effect of sanding on surface roughness of rubberwood. Journal of Materials Processing Technology 209: 3949-3955.

Taylor AM, Gartner BL \& Morrell JJ. 2007. Heartwood formation and natural durability-a review. Wood and Fiber Science 34: 587-611.
Tenorio C, Moya R \& Quesada-Pineda HJ. 2012. Kiln drying of Acacia mangium wood: colour, shrinkage, warp, split and check in dried lumber. Journal of Tropical Forest Science 24: 125-139.

WÅlinder ME \& Johansson I. 2001. Measurement of wood wettability by the Wilhelmy method. Part 1: contamination of probe liquids by extractives. Holzforschung 55: 21-32. 